\title{
BANKING SECURITY MONITORING: DEVELOPMENT OF A METHODICAL SUPPORT TO VALUATION
}

\author{
Yuliia Diatlova', Svitlana Yeletskykh ${ }^{2}$, Valentyna Bykhovchenko ${ }^{3}$, Kateryna Balabukha ${ }^{4}$, Ievgen \\ Ovcharenko $^{5 *}$, Volodymyr Tyshchenko ${ }^{6}$
}

${ }^{1}$ Assoc. Prof. Dr. Sc. (Econ), Donetsk State University of Management. Karpinskoho str. 58. 87513.

Mariupol. Ukraine. Phone: +380500471466,Email: yuliyadyatlova25@gmail.com

${ }^{2}$ Prof. Dr. Sc. (Econ), Donbass State Engineering Academy. Akademichna str. 72. 84313. Kramatorsk. Ukraine. Phone: +380502222453, Email: svetlana.eleckyh@gmail.com

${ }^{3}$ Assoc. Prof. PhD (Econ), National University of Life and Environmental Sciences of Ukraine. Heroiv Oborony str. 11. 03041. Kyiv. Ukraine. Phone: +380974552658,Email:vpkrot@gmail.com

${ }^{4}$ PhD (Public Administration), Classic Private University. Zhukovsky str. 70-b. 69002. Zaporizhzhia. Ukraine. Phone: +380974486380, Email: balabuhakaterina@ukr.net

${ }^{5}$ Prof. Dr. Sc. (Econ), Volodymyr Dahl East Ukrainian National University. Tsentralnyi Prospect, 59-a. 93406. Severodonetsk. Ukraine.Phone: +380507669666,_Email: ovcharenko_ievgen@ukr.net

${ }^{6}$ Assoc. Prof. PhD (Econ), Volodymyr Dahl East Ukrainian National University. Tsentralnyi Prospect, 59-a. 93406. Severodonetsk. Ukraine.Phone: +380502542330,Email: tischenko@snu.edu.ua

Received 2103 2021; Accepted 13042021

\begin{abstract}
Topicality of research into banking security is justified by growing importance of the banking sector in financing the development of countries and vulnerability to cyclical crises. The purpose of the article is to develop a methodology for assessing the security of the banking sector in a crisis. Security is relevant for the banking sector as entrepreneurship. The scientific work proposes a methodical support. The sequential stages of evaluation are identified, such as the formation of a set of indices; determination of characteristic values of indices; normalization of indices; determination of weighting coefficients; calculation of the complex indicator. The set of banking security indices has been expanded to include indices that are important from the point of view of lending to the development of the economy and the economic security of the banking sector. The characteristic values of the proposed indices have been determined. The weighting coefficients of indices are set by an expert method. Methodical support for monitoring is based on the calculation of a complex banking security indicator and determination of its level according to the established gradations. The results indicate the expediency of monitoring and using effective tools to influence the state of banking security to improve its level.
\end{abstract}

Keywords: banking sector, security, methodical approach, evaluation, sequential stages, indices, normalization, weighting coefficients, expert method, complex indicator, monitoring.

JEL Codes: G21, G18.

\section{Introduction}

The problem of providing economic security in the format of countries development and various sectors of the global market is relevant to science and practice. Therefore, scientists are studying various aspects of economic security - financial (Onyshchuk, Onyshchuk, Petroye, Chernysh, 2020), investment (Kwilinski, Dielini, Mazuryk, Filippov, Kitseliuk, 2020), banking (Ponomarenko, Prokopenko, Kuzmenko,

Copyright (C) 2021 Author(s), published by Vytautas Magnus University. This is an open access article distributed under the terms of the Creative Commons Attribution Non-Commercial 4.0 (CC BY-NC 4.0) license, which permits unrestricted use, distribution, and reproduction in any medium provided the original author and source are credited. The material cannot be used for commercial purposes. 
Kaminska, Luchyk, 2018). Scientists are unanimous about the importance of the banking system as a pole of economic growth (Zaitseva, 2020; Pradhan, Arvin, Nair, Hall, Gupta, 2017). The relevance of the study determines the importance of the banking sector and its economic security.

The problem of banking security is relevant for all countries. Ukraine is no exception. There have been many crises in the banking system caused by external and internal risks. Open access of foreign banks to the domestic banking services market, deterioration of the financial condition and security of both individual commercial banks and the entire banking system after the crisis of 2014-2016, requires a search for better measures at the central bank level. In this context, the issue of monitoring the security of the banking system and in particular the commercial sector as one of the main components of the country's economic security is relevant.

Such Ukrainian scientists as O. Baranovskyi, A. Epifanov, V. Kovalenko, I. Krupka, L. Pylypenko, V. Soloviov, L. Shtefan and others dealt with the problem of banking security assessment within the framework of their scientific research. In scientific works, the analysis of indicators for assessing banking security and monitoring compliance with the requirements of established standards is mainly given. Meanwhile, it is important to conduct monitoring as a systematic tracking of indicators that characterize a process, phenomenon, and situation. Attention is drawn to need for monitoring in the studies of banking security by foreign scientists such as Cooper (2009), Palvia (2011). Domestic scientists point to the monitoring nature of observations regarding specific banking operations (Danylchuk, Kovtun, Kibalnyk, Sysoiev, 2020; Leonov, Yarovenko, Boiko, Dotsenko, 2019). Scientists believe that monitoring ensures the identification of discrepancies in indicators from the planned ones for timely overcoming or reducing undesirable trends in the development of processes.
Many scientists and specialists from different countries are researching monitoring in the banking system. Most of the scientific works are related to financial monitoring. G. Hale and J. Lopez (2019) research to the importance of monitoring, including with a procedure that generates measures of connectedness between individual firms and for the system as a whole. The study presents the results of a network analysis of large United States bank holding companies and the measurement of relationships between financial firms, indicating connectedness within (and across) national banking systems. Scientists suggest measures that can be useful for monitoring the financial stability of firms.

S. Leonov, H. Yarovenko, A. Boiko, and T. Dotsenko (2019) emphasize the need for state regulators to intensify the internal banking system of financial monitoring by developing appropriate coercive regulatory legal acts. The authors suggest the prototype of the information system for intrabank monitoring transactions. As a result of development universal components of system of financial monitoring of any bank are received.
A. Bukhtiarova
A. Semenog, M. Razinkova, N. Nebaba, and J. Haber (2020) discuss the issues of assessing the effectiveness of financial monitoring in the banking system of the Ukraine. The research presents the improved method that quantifies the level of financial monitoring system effectiveness at commercial banks of Ukraine based on calculations of the integral index. The index indicates the dynamics of the financial system protection degree from the money laundering through the banking system.

Currently, financial monitoring of the banking system has been introduced in many countries (McPhilemy, 2016; Hui, Zhang, 2020). Experts from international financial institutions and specialists from central banks of economically developed countries have made efforts to introduce macroprudential monetary policy instruments that ensure the financial stability of national banking systems. Macroprudential indicators are used to monitor and neutralize the risks that have arisen in the 


\section{Sciendo}

Management Theory and Studies for Rural Business and Infrastructure Development

eISSN 2345-0355. 2021. Vol. 43. No. 2: 206 -216

Article DOI: https://doi.org/10.15544/mts.2021.17

system (Arnold, Borio, Ellis, Moshirian, 2012; Borio, 2011).

Risks in the banking sector are related to risks in other sectors of the economy, including foreign trade. In the research scientists substantiated that after 2013 the global indicator for Ukraine of import coverage by export has entered the area of critical risk, and from 2020 may enter the area of catastrophic risk (Fokina-Mezentseva, Melnyk, Diatlova, Buhas, Shatska, 2020). The country's importdependence will also affect the banking sector's performance, including profitability.

Researchers, studying banking security, pay attention not only to financial stability. Scientists are also investigating the economic security of banks (Mihus, Haman, Andriyenko, Koval, 2019; Diatlova, 2018). This is quite logical, because, on the one side, the banking sector is an element of the financial system, on the other - the activities of a commercial bank are entrepreneurial.

Ukrainian scientists in determining banking security use the "Methodical recommendations" adopted by the Ministry of economic development and trade of Ukraine (2013). The importance of security types at the state level can be traced by the values of their weighting coefficients in accordance with the specified methodical document. Of all the types of economic security, financial security is the most significant. Within the framework of financial security, the values of the weighting coefficients by its types are distributed as follows: banking - 0.1723 , non-banking financial market -0.1068 , debt -0.1746 , budget -0.2023 , currency -0.1686 , monetary -0.1753 .

M. Zos-Kior, I. Hnatenko, O. Isai, I. Shtuler, O. Samborskyi, V. Rubezhansk (2021) focus their attention on the activities of the development of bank lending, ensuring banking security in the context of the effective management of energy and resource-saving innovative projects at processing enterprises.
Improvements in the assessment of the banking security level were made on the basis of the content analysis of the "Methodical recommendations". First of all, security indicators do not reflect the efficiency and the riskiness of banking business, which is important for banking. In this regard, the methodology requires improvement from the point of view of the scientific substantiation of the set of indices and their weighting coefficients.

\section{Research results and discussion}

The analysis of the scientific literature and recommendations for the assessment of banking security suggests that obtaining a complex indicator of banking security involves the following stages: formation of a set of indices; determination of characteristic values of indices; normalization of indices; determination of weighting coefficients of indices; calculation of the complex indicator.

So, the first step is to form a set of indices. We believe that relative indices should be used to assess the level of banking security. Indices from the "Methodical recommendations for calculating the level of economic security of Ukraine" are taken as a basis. However, the set of indices needs to be expanded to include those that reflect the activities of the banking sector as a type of entrepreneurship, as well as those that reflect the possible impact on the real sector of the economy through lending. The set of indices taken to assess the security of the banking sector and the order of their calculations are given in Table 1. The set of indices has been expanded by introducing such as return on capital (important from the point of view of banking as a type of entrepreneurship), asset sufficiency ratio (important from the point of view of lending to economic development), credit risk (important from the point of view of economic security of the banking sector).

Copyright (C) 2021 Author(s), published by Vytautas Magnus University. This is an open access article distributed under the terms of the Creative Commons Attribution Non-Commercial 4.0 (CC BY-NC 4.0) license, which permits unrestricted use, distribution, and reproduction in any medium provided the original author and source are credited. The material cannot be used for commercial purposes. 


\section{Table 1. Banking security assessment indices and the procedure for their calculations}

\begin{tabular}{|l|l|}
\hline Name of indicator, unit of measurement & The formula for calculating the indicator \\
\hline $\begin{array}{l}\text { 1. Share of overdue debt on loans in the } \\
\text { rotal amount of loans granted by banks to } \\
\text { residents of country, percent }\end{array}$ & Overdue loans, UAH million / Loans granted, UAH million * 100 \\
\hline $\begin{array}{l}\text { 2. Ratio of bank loans and deposits in } \\
\text { foreign currency, percent }\end{array}$ & $\begin{array}{l}\text { Loans to residents, UAH million / Deposits attracted by depository } \\
\text { corporations from residents, UAH million * 100 }\end{array}$ \\
\hline $\begin{array}{l}\text { 3. Share of foreign capital in the } \\
\text { authorized capital of banks, percent }\end{array}$ & $\begin{array}{l}\text { Capital of banks in foreign currency, UAH million / Authorized capital } \\
\text { of banks, UAH million * 100 }\end{array}$ \\
\hline $\begin{array}{l}\text { 4. Ratio of long-term (over 1 year) loans } \\
\text { and deposits, times }\end{array}$ & $\begin{array}{l}\text { Loans granted to residents for a period of 1 to 5 years, UAH million + } \\
\text { loans granted to residents for a period of more than 5 years, UAH } \\
\text { million / Deposits attracted from residents) for a period of 1 to 5 years, } \\
\text { UAH million + deposits attracted from residents for a period of more } \\
\text { than 5 years, UAH million }\end{array}$ \\
\hline 5. Return on assets, percent & Operating profit, UAH million / Assets, UAH million * 100 \\
\hline $\begin{array}{l}\text { 6. Ratio of liquid assets to short-term } \\
\text { liabilities, percent }\end{array}$ & Liquid assets, UAH million / Short-term liabilities, UAH million * 100 \\
\hline $\begin{array}{l}\text { 7. Share of assets of the five largest banks } \\
\text { in the total assets of the banking system, } \\
\text { percent }\end{array}$ & $\begin{array}{l}\text { Assets of the five largest banks by assets, UAH million / Assets of } \\
\text { banks, total, UAH million * 100 }\end{array}$ \\
\hline 8. Return on capital, percent & Profit of banks, UAH million / Capital, UAH million * 100 \\
\hline 9. Asset sufficiency ratio, percent & $\begin{array}{l}\text { Bank assets, UAH million / Gross domestic product, UAH million * } \\
100\end{array}$ \\
\hline 10. Credit risk, percent & $\begin{array}{l}\text { Financial liabilities of counterparties, UAH million / Loans granted by } \\
\text { banks to residents of Ukraine, UAH million * 100 }\end{array}$ \\
\hline
\end{tabular}

The second stage is to determine the characteristic values of the indices.

The range of characteristic values of each index is measured from 0 to 1 (or from 0 to 100 percent) and is divided into five intervals:

$\left[y_{0}, y_{\text {crit }}\right)\left[y_{\text {crit }}, y_{\text {dang }}\right)\left[y_{\text {dang }}, y_{\text {unsat }}\right)\left[y_{\text {unsat }}, y_{\text {sat }}\right)\left[y_{\text {sat }}\right.$, $\left.y_{\text {opt }}\right]$,

where $y_{0}$ is the index value, which is characterized as a minimum level and at which the level of economic security is $0 ; y_{\text {crit }}$ is the index value, which is characterized as a critical and at which the level of economic security is 0.2 , or $20 \%$ of the optimal value; $y_{\text {dang }}$ is the index value, which is characterized as a dangerous level and at which the level of economic security is 0.4 , or $40 \%$ of the optimal value; $y_{\text {unsat }}$ is the index value, which is characterized as an unsatisfactory level and at which the level of economic security is 0.6 , or $60 \%$ of the optimal value; $y_{\text {sat }}$ is the index value, which is characterized as a satisfactory level and at which the level of economic security is 0.8 , or $80 \%$ of the optimal value; $y_{\text {opt }}$ is the index value, which is characterized as the optimal level and at which the level of economic security is 1 .
The assignment of characteristic values for index is carried out as follows:

$$
\begin{gathered}
y_{0}:=x_{0} ; y_{\text {crit }}:=x_{\text {crit }} ; y_{\text {dang }}:=x_{\text {dang }} ; y_{\text {unsat }}:=x_{\text {unsat }} ; \\
y_{\text {sat }}:=x_{\text {sat }} ; y_{\text {opt }}:=x_{\text {opt }},
\end{gathered}
$$

where $x$ is the value (statistical data) of the indicator; $y$ is the characteristic value of the indicator.

The indices are divided into stimulants, de-stimulants and mixed. An index is a stimulant if there is a direct connection between it and a complex indicator. An index is a de-stimulant when there is a feedback between it and the complex indicator. A mixed index is that, according to certain values, it is a stimulant, and in the case of their further increase, it turns into a de-stimulant relative to a complex indicator.

The third stage is the normalization of indices to bring them to informational unidirectionality and dimensionality of the characteristic values interpretation. The normalization of each index $\left(y_{i j}\right)$ was carried out by the calculation method: index-stimulant according to the formula (3), index-destimulant according to formula (4): 


\section{Sciendo}

Management Theory and Studies for Rural Business and Infrastructure Development

eISSN 2345-0355. 2021. Vol. 43. No. 2: 206 -216

Article DOI: https://doi.org/10.15544/mts.2021.17

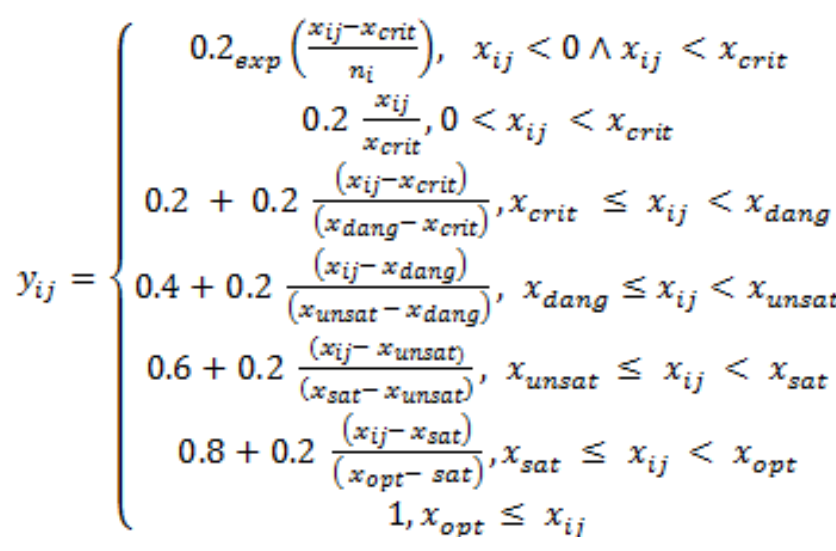

$$
\begin{aligned}
& y_{i j}=\left\{\begin{array}{c}
1, x_{i j}<x_{\text {opt }} \\
0.8+0.2 \frac{\left(x_{\text {sat }}-x_{i j}\right)}{\left(x_{\text {sat }}-x_{\text {opt }}\right)}, x_{\text {opt }} \leq x_{i j}<x_{\text {sat }} \\
0.6+0.2 \frac{\left(x_{\text {unsat }}-x_{i j}\right)}{\left(x_{\text {unsat }}-x_{\text {sat }}\right)}, x_{\text {sat }} \leq x_{i j}<x_{\text {unsat }} \\
0.4+0.2 \frac{\left(x_{\text {dang }}-x_{i j}\right)}{\left(x_{\text {dang }}-x_{\text {unsat }}\right)}, x_{\text {unsat }} \leq x_{i j}<x_{\text {dang }} \\
\left.0.2+0.2 \frac{\left(x_{\text {crit }}-x_{i j}\right)}{\left(x_{\text {crit }}-x_{\text {dang }}\right)}\right) \\
0.2 \frac{x_{\text {crit }}}{x_{i j}}, x_{i j} \geq x_{\text {dang }} \leq x_{i j}<x_{\text {crit }}
\end{array}\right.
\end{aligned}
$$

where $x_{i j}$ is value of the $i$-th index in the period $j$ ( $x_{o p t}$ - optimal level, $x_{s a t}$ - satisfactory level, $x_{u n s a t}-$ unsatisfactory level, $x_{d a g n}$ - dangerous level, $x_{c r i t}$ - critical level); $y_{i j}$ is normalized value of the index $x_{i j}$; $z_{i}$ is smoothing constant, for each index is determined separately by experts.

In the interval between the optimal values of index-stimulant and index-destimulant, the normalized value is equal to 1 .

The fourth stage is the determination of weighting coefficients of indices.

The weighting coefficients and threshold values of the indices were established by the expert method. Thirty experts took part in the survey. The survey of experts was carried out in the form of a standardized interview, which provided for answers to the questions posed in a formalized form (score on a ten-point scale).

The information obtained as a result of the survey allowed in the further analysis to use average expert assessments, which characterized the importance of each index for generalized objects or influential interrelated factors in complex systems.
The calculation of the weighting coefficients for each index was carried out according to the formula:

$$
w_{i}=\frac{\overline{a_{i}}}{\sum_{i=1}^{10} \overline{a_{i}}},
$$

where $i$ is the index, $i=(1,2,3 \ldots 10) ; a_{i}$ is expert assessment, which characterizes the importance of the $i$-th index to the complex indicator of banking security; $w_{i}$ is the weighting coefficient that determines the degree of contribution of the $i$-th index to the complex indicator of banking security.

The fifth stage is the calculation of the complex indicator. The complex indicator of banking security $\left(C_{e s b s}\right)$ was calculated by the formula:

Copyright (C) 2021 Author(s), published by Vytautas Magnus University. This is an open access article distributed under the terms of the Creative Commons Attribution Non-Commercial 4.0 (CC BY-NC 4.0) license, which permits unrestricted use, distribution, and reproduction in any medium provided the original author and source are credited. The material cannot be used for commercial purposes. 


$$
C_{e s b s}=\sum_{i=1}^{10} y_{i} \cdot w_{i}
$$

where $w_{i}$ is the weighting coefficient of the normalized index; 10 is the number of index; $y_{i}$ is the values of normalized index.

At the same time,

$$
0 \leq w_{i} \leq 1, \quad \sum_{i=1}^{10} w_{i}=1, \quad 0 \leq \mathrm{y}_{\mathrm{i}} \leq 1 .
$$

The following gradations for the complex indicator of banking security $\left(C_{e s b s}\right)$ has been adopted:

$$
0.0<C_{e s b s}<0.2-\text { minimum; } \quad 0.2 \leq
$$
$C_{e s b s}<0.4-$ critical;

$0.4 \leq C_{e s b s}<0.6$ - dangerous; $\quad 0.6 \leq$ $C_{e s b s}<0.8$ - unsatisfactory;
$0.8 \leq C_{e s b s}<1.0-$ satisfactory; $C_{e s b s}=$ 1.0 - optimal.

Ten indices are divided into stimulants, de-stimulants and mixed.

As an index-stimulant is the proposed asset sufficiency ratio.

Set of indices-de-stimulants include: share of overdue debt on loans in the total amount of loans granted by banks to residents of country; ratio of long-term (over 1 year) loans and deposits; share of assets of the five largest banks in the total assets of the banking system; credit risk (proposed index).

Set of mixed indices include: ratio of bank loans and deposits in foreign currency; share of foreign capital in the authorized capital of banks; return on assets; ratio of liquid assets to short-term liabilities; return on capital (proposed indicator).

The characteristic values of indices for

\begin{tabular}{|c|c|c|c|c|c|c|c|c|c|c|}
\hline \multirow{3}{*}{ Name of indicator, unit of measurement } & \multicolumn{10}{|c|}{ Characteristic values of index* } \\
\hline & $\mathrm{X}^{\mathrm{L}}$ & $\mathrm{X}^{\mathrm{L}}$ & $\mathrm{X}^{\mathrm{L}}$ & $\mathrm{X}^{\mathrm{L}}$ & $\mathrm{X}^{\mathrm{L}}$ & $\mathrm{X}^{\mathrm{R}}$ & $\mathrm{X}^{\mathrm{R}}$ & $\mathrm{X}^{\mathrm{R}}$ & $\mathrm{X}^{\mathrm{R}}$ & $\mathrm{X}^{\mathrm{R}}$ \\
\hline & crit & dang & unsat & sat & opt & opt & stat & unsat & dang & \\
\hline $\begin{array}{l}\text { 1. Share of overdue debt on loans in the total amount of loans } \\
\text { granted by banks to residents of country, percent }\end{array}$ & & & & & & 2 & 3 & 4 & 5 & 7 \\
\hline $\begin{array}{l}\text { 2. Ratio of bank loans and deposits in foreign currency, } \\
\text { percent }\end{array}$ & 50 & 70 & 80 & 85 & 90 & 110 & 130 & 140 & 160 & 180 \\
\hline $\begin{array}{l}\text { 3. Share of foreign capital in the authorized capital of banks, } \\
\text { percent }\end{array}$ & 10 & 12 & 15 & 18 & 20 & 25 & 30 & 35 & 40 & 60 \\
\hline 4. Ratio of long-term (over 1 year) loans and deposits, times & & & & & & 1 & 1.2 & 1.8 & 2.2 & 3 \\
\hline 5. Return on assets, percent & -1 & 0 & 0 & 0.5 & 1 & 1.5 & 2 & 2.5 & 3 & 3.5 \\
\hline 6. Ratio of liquid assets to short-term liabilities, percent & 0.5 & 0.65 & 0.8 & 0.85 & 1 & 1.0 & 1.5 & 1.8 & 2 & 3 \\
\hline $\begin{array}{l}\text { 7. Share of assets of the five largest banks in the total assets } \\
\text { of the banking system, percent }\end{array}$ & & & & & & 30 & 35 & 40 & 50 & 60 \\
\hline 8. Return on capital, percent & -1 & 0 & 0 & 5 & 10 & 15 & 20 & 25 & 30 & 35 \\
\hline 9. Asset sufficiency ratio, percent & 30 & 40 & 50 & 60 & 80 & & & & & \\
\hline 10. Credit risk, percent & & & & & & 10 & 12 & 15 & 20 & 25 \\
\hline
\end{tabular}
rationing are given in Table 2.

Table 2. Characteristic values of indices for rationing

$* \mathrm{X}^{\mathrm{L}}$ - index-stimulant $\left(\mathrm{X}_{\text {crit }}^{\mathrm{L}}\right.$ - critical level, $\mathrm{X}_{\text {dagn }}-$ dangerous level, $\mathrm{X}_{\text {unsat }}^{\mathrm{L}}$ - unsatisfactory level, $\mathrm{X}_{\text {sat }}$ - satisfactory level, $\mathrm{X}^{\mathrm{L}}$ opt - optimal level); $\mathrm{X}^{\mathrm{R}}$ - index-de- stimulant $\left(\mathrm{X}_{\text {opt }}^{\mathrm{R}}\right.$ optimal level, $\mathrm{X}_{\text {sat }}^{\mathrm{R}}$ - satisfactory level, $\mathrm{X}^{\mathrm{R}}$ unsat unsatisfactory level, $\mathrm{X}_{\text {dagn }}^{\mathrm{R}}$ - dangerous level, $\mathrm{X}^{\mathrm{R}}$ crit - critical level).

The characteristic values for the new introduced indices were established by the expert method. The value of the concordance coefficient indicated a sufficient level of experts' opinions coherence.
The weighting coefficients for each index are as follows (Table 3). Share of overdue debt on loans in the total amount of loans granted by banks to residents has the largest weighting coefficient, credit risk - the smallest. 


\section{Sciendo}

Management Theory and Studies for Rural Business and Infrastructure Development eISSN 2345-0355. 2021. Vol. 43. No. 2: 206 -216

Article DOI: https://doi.org/10.15544/mts.2021.17

Table 3. Weighting coefficients of indices for rationing

\begin{tabular}{|l|l|l|l|}
\hline \multicolumn{1}{|c|}{ Name of indicator, unit of measurement } & $\begin{array}{c}\text { Weighting } \\
\text { coefficients }\end{array}$ & \multicolumn{1}{|c|}{$\begin{array}{c}\text { Name of indicator, unit of } \\
\text { measurement }\end{array}$} & $\begin{array}{c}\text { Weighting } \\
\text { coefficients }\end{array}$ \\
\hline $\begin{array}{l}\text { 1. Share of overdue debt on loans in the total } \\
\text { amount of loans granted by banks to } \\
\text { residents of country, percent }\end{array}$ & 0.1532 & $\begin{array}{l}\text { 6. Ratio of liquid assets to short-term } \\
\text { liabilities, percent }\end{array}$ & 0.1065 \\
\hline $\begin{array}{l}\text { 2. Ratio of bank loans and deposits in } \\
\text { foreign currency, percent }\end{array}$ & 0.1455 & $\begin{array}{l}\text { 7. Share of assets of the five largest } \\
\text { banks in the total assets of the } \\
\text { banking system, percent }\end{array}$ & 0.0909 \\
\hline $\begin{array}{l}\text { 3. Share of foreign capital in the authorized } \\
\text { capital of banks, percent }\end{array}$ & 0.1351 & 8. Return on capital, percent & 0.0779 \\
\hline $\begin{array}{l}\text { 4. Ratio of long-term (over 1 year) loans and } \\
\text { deposits, times }\end{array}$ & 0.1273 & 9. Asset sufficiency ratio, percent & 0.0675 \\
\hline 5. Return on assets, percent & 0.1065 & 10. Credit risk, percent & 0.0571 \\
\hline
\end{tabular}

The initial data for calculating the compiled according to the official data of the security of Ukrainian banking sector were

National Bank of Ukraine (Table 4).

Table 4. Initial data for calculating the security of Ukrainian banking sector*

\begin{tabular}{|l|l|l|l|l|}
\hline Initial data & $01.01 . .2016$ & 01.01 .2017 & 01.01 .2018 & 01.01 .2019 \\
\hline Loans granted, UAH million & 981627 & 998682 & 1016657 & 1118860 \\
\hline Overdue loans, UAH million & 223836 & 536292 & 594999 & 630767 \\
\hline Loans to residents in foreign currency, UAH million & 547802 & 493683 & 446031 & 459137 \\
\hline $\begin{array}{l}\text { Deposits attracted by depository corporations from residents in } \\
\text { foreign currency, UAH million }\end{array}$ & 324817 & 367056 & 407872 & 392284 \\
\hline Capital of banks in foreign currency, UAH million & 86465.2 & 144737.4 & 159361.2 & 125706.6 \\
\hline Authorized capital of banks, UAH million & 212921.3 & 296331.4 & 488217.6 & 465532.0 \\
\hline $\begin{array}{l}\text { Loans granted to residents for a period of 1 to 5 years, UAH million } \\
\text { + loans granted to residents for a period of more than 5 years, UAH } \\
\text { million }\end{array}$ & 868382 & 954814 & 936589 & 900251 \\
\hline $\begin{array}{l}\text { Deposits attracted from residents for a period of 1 to 5 years, UAH } \\
\text { million + deposits attracted from residents for a period of more than } \\
\text { 5 years, UAH million }\end{array}$ & 226313 & 255674 & 310723 & 260424 \\
\hline Return on assets, percent & & -5.46 & -12.6 & -1.93 \\
\hline Liquid assets, UAH million & 339389 & 400748 & 463225 & 503408 \\
\hline Short-term liabilities, UAH million & 661047 & 537551 & 526098 & 632017 \\
\hline Assets of the five largest banks by assets, UAH million & 647122.2 & 692457.6 & 1171790.3 & 1178049.6 \\
\hline Assets of banks, total, UAH million & 1254385 & 1256299 & 1333831 & 1360764 \\
\hline Return on capital, percent & -51.91 & -116.74 & -15.84 & 14.67 \\
\hline Bank assets, UAH million & 1254385 & 1256299 & 1333831 & 1360764 \\
\hline Gross domestic product, UAH million & 1979458 & 2383182 & 2982920 & 3558706 \\
\hline \begin{tabular}{l} 
Financial liabilities of counterparties, UAH million \\
\hline
\end{tabular} & $\begin{array}{l}1168665, \\
4\end{array}$ & 669891 & 264929 & 322981 \\
\hline
\end{tabular}

*Presented Statistics of the National Bank of Ukraine (2016-2019).

The calculated values of the indices selected to determine the level of security of Ukrainian banking sector are given in Table 5 .

Copyright (C) 2021 Author(s), published by Vytautas Magnus University. This is an open access article distributed under the terms of the Creative Commons Attribution Non-Commercial 4.0 (CC BY-NC 4.0) license, which permits unrestricted use, distribution, and reproduction in any medium provided the original author and source are credited. The material cannot be used for commercial purposes. 


\section{Table 5. Values of the indices to determine the level of security of Ukrainian banking sector}

\begin{tabular}{|c|c|c|c|c|}
\hline Index & 01.01.2016 & 01.01.2017 & 01.01.2018 & 01.01.2019 \\
\hline $\begin{array}{l}\text { 1. Share of overdue debt on loans in the total amount of loans granted } \\
\text { by banks to residents of country, percent }\end{array}$ & 22.8 & 53.7 & 58.5 & 56.4 \\
\hline 2. Ratio of bank loans and deposits in foreign currency, percent & 168.65 & 134.49 & 109.36 & 117.04 \\
\hline 3. Share of foreign capital in the authorized capital of banks, percent & 40.6 & 48.8 & 32.6 & 27.0 \\
\hline 4. Ratio of long-term (over 1 year) loans and deposits, times & 3.84 & 3.73 & 3.01 & 3.46 \\
\hline 5. Return on assets, percent & -5.46 & -12.6 & -1.93 & 1.69 \\
\hline 6. Ratio of liquid assets to short-term liabilities, percent & 51.34 & 74.55 & 88.05 & 79.65 \\
\hline $\begin{array}{l}\text { 7. Share of assets of the five largest banks in the total assets of the } \\
\text { banking system, percent }\end{array}$ & 51.59 & 55.12 & 87.85 & 83.08 \\
\hline 8. Return on capital, percent & -51.91 & -116.74 & -15.84 & 14.67 \\
\hline 9. Asset sufficiency ratio, percent & 63.37 & 52.71 & 44.72 & 38.24 \\
\hline 10. Credit risk, percent & 119.1 & 67.1 & 26.1 & 28.9 \\
\hline
\end{tabular}

In accordance with the change in the values of the indices, the trends in the state of economic banking security are as follows.

There is an increase in the values of the index "share of overdue debt on loans in the total amount of loans granted by banks to residents" from $22.8 \%$ to $56.4 \%$. The highest value of the index was noted at the beginning of $2018-58.5 \%$. The value of the index is increasing, because the growth rate of overdue debt on loans due to non-repayment by debtors-clients is higher than the growth rate of loan amounts.

It was found that the value of the index "ratio of bank loans and deposits in foreign currency" for the analyzed period decreases from $168.65 \%$ to $117.04 \%$. The lowest value was noted at the beginning of $2019-109.36 \%$. This means that the attracted deposits in foreign currency do not cover the loans provided to residents in this currency, which negatively characterizes the activity of the banking sector. However, the downward trend in the index value is positive.

The change in the index "share of foreign capital in the authorized capital of banks" generally tends to decrease. Therefore, at the beginning of 2016, the value of the index was $40.6 \%$, and at the beginning of 2019, it increased to $27.0 \%$. The downward trend in the indicator value indicates the withdrawal of capital of foreign banking groups from Ukrainian banking system. The simultaneous increase for bank authorized capital due to the introduction of the requirements of National Bank of Ukraine in 2016 made it possible to financially strengthen banks with domestic capital in the domestic market.

The main trend of change in the index "the ratio of long-term (over 1 year) loans and deposits" is a decrease. This is positive. The highest value of this index was observed in early 2016, the lowest - in early 2018. The integral long-term credit rating of Ukrainian banking system has grown. Thus, at the beginning of 2016 the rating was uaBBB+, and the beginning of 2019 as uaA+.

The return on assets index has a positive trend. At the beginning of 2019, this figure was $1.69 \%$ with a positive mark. Whereas in previous years this indicator was negative, which indicates the unsatisfactory performance of banks.

Liquid assets have been growing since the beginning of 2016, and short-term liabilities are declining. Therefore, the index of their ratio is growing. This trend positively characterizes the activity of the banking sector. Meanwhile, we should pay attention to the fact that the indicator decreased, the value of which at the beginning of 2018 was $88.05 \%$, and at the beginning of $2019-79.65 \%$. Banks should pay attention to this to correct the trend.

The value of the index "share of assets of the five largest banks in the total assets of the banking system" decreased from $51.59 \%$ at the beginning of 2016 to $83.08 \%$ at the beginning of 2019. This is a positive trend in the banking sector. This was primarily due to a decrease in the assets of the five largest banks with some increase in the assets of the banking sector. In addition, the number of banking institutions in 


\section{Sciendo}

Management Theory and Studies for Rural Business and Infrastructure Development eISSN 2345-0355. 2021. Vol. 43. No. 2: 206 -216

Article DOI: https://doi.org/10.15544/mts.2021.17

the banking system decreased as the National Bank of Ukraine increased the value of regulatory indicators of financial stability.

Return on capital has increased, which is a positive trend. This is evidenced by the positive value of this index at the beginning of $2019-14.67 \%$. In previous years, the return on capital was negative, with the highest at the beginning of 2017

$-116.74 \%$.

The value of the index "asset adequacy" was decreasing over the analyzed period. Thus, at the beginning of 2016 the value of the index was $63.37 \%$, and at the beginning of 2019 - by $25.13 \%$ less. This trend is negative and to some extent indicates a decrease in the efficiency of banking institutions and their impact on economic growth, even given that gross domestic product and assets of the banking sector are growing. The value of the index by country is different, for example in 2017 in Belarus - 61.6\%, in Poland - 89.7\%, but higher than in Ukraine. In economically developed countries, the ratio of assets to gross domestic product is more than $100 \%$.

The value of the index "credit risk" for the analyzed period decreased by 4 times. At the beginning of 2016, the index was $119.1 \%$, and at the beginning of $2019-28.9 \%$. This is a positive trend and indicates a decrease in the probability of financial losses in the banking sector.

Therefore, the selected indices have different trends. This confirms the feasibility of using a complex indicator of the banking sector security.

The calculated values of normalized security indices $\left(\mathrm{y}_{\mathrm{i}}\right)$ of Ukrainian banking sector for the analyzed period are given in Table 6.

\section{Table 6. Values of normalized indices of economic security of Ukrainian banking sector}

\begin{tabular}{|l|l|l|l|l|}
\hline Index & $\mathbf{0 1 . 0 1 . 2 0 1 6}$ & $\mathbf{0 1 . 0 1 . 2 0 1 7}$ & $\mathbf{0 1 . 0 1 . 2 0 1 8}$ & $\mathbf{0 1 . 0 1 . 2 0 1 9}$ \\
\hline $\begin{array}{l}\text { 1. Share of overdue debt on loans in the total amount of loans granted } \\
\text { by banks to residents of country, percent }\end{array}$ & 0.0614 & 0.0261 & 0.0239 & 0.0248 \\
\hline 2. Ratio of bank loans and deposits in foreign currency, percent & 0.3135 & 0.7102 & 1.0000 & 0.9296 \\
\hline 3. Share of foreign capital in the authorized capital of banks, percent & 0.3940 & 0.3120 & 0.6960 & 0.9200 \\
\hline 4. Ratio of long-term (over 1 year) loans and deposits, times & 0.1563 & 0.1609 & 0.1993 & 0.1734 \\
\hline 5. Return on assets, percent & 0.0023 & 0.0000 & 0.0789 & 0.9240 \\
\hline 6. Ratio of liquid assets to short-term liabilities, percent & 0.0117 & 0.0080 & 0.0068 & 0.0075 \\
\hline $\begin{array}{l}\text { 7. Share of assets of the five largest banks in the total assets of the } \\
\text { banking system, percent }\end{array}$ & 0.3682 & 0.2976 & 0.1366 & 1.0000 \\
\hline 8. Return on capital, percent & 0.0000 & 0.0000 & 0.0000 & 1.0000 \\
\hline 9. Asset sufficiency ratio, percent & 0.8337 & 0.6542 & 0.4944 & 0.3648 \\
\hline 10. Credit risk, percent & 0.0420 & 0.0745 & 0.1916 & 0.1730 \\
\hline
\end{tabular}

The results of calculations on the values of the complex indicator of economic security of Ukrainian banking sector for the analyzed period are given in Table 7 .

Copyright ( 2021 Author(s), published by Vytautas Magnus University. This is an open access article distributed under the terms of the Creative Commons Attribution Non-Commercial 4.0 (CC BY-NC 4.0) license, which permits unrestricted use, distribution, and reproduction in any medium provided the original author and source are credited. The material cannot be used for commercial purposes. 
Table 7. Complex indicator of economic security of Ukrainian banking sector

\begin{tabular}{|l|l|l|l|l|}
\hline \multicolumn{1}{|c|}{ Indicator } & $\mathbf{0 1 . 0 1 . 2 0 1 6}$ & $\mathbf{0 1 . 0 1 . 2 0 1 7}$ & $\mathbf{0 1 . 0 1 . 2 0 1 8}$ & $\mathbf{0 1 . 0 1 . 2 0 1 9}$ \\
\hline Complex indicator & 0.2073 & 0.2342 & 0.3239 & 0.5587 \\
\hline Increase to the previous year & - & 0.0269 & 0.0897 & 0.2348 \\
\hline
\end{tabular}

The value of the complex indicator increases from 0.2073 at the beginning of 2016 to 0.5587 at the beginning of 2019 . The value of the indicator to the previous year also tends to increase.

The obtained values of the complex indicator indicate the critical state for economic security of Ukrainian banking sector until 2018, which at the beginning of 2019 deteriorated and became dangerous, according to the accepted gradation of its level. The growth values of the complex indicator compared to the previous year indicate that the situation with banking security is deteriorating rapidly.

\section{Conclusions}

The banking security requires systemic monitoring to determine its state in the country, taking into account the importance of the issue. The methodical support for monitoring is based on the calculation of a complex banking security indicator and determination of its level according to the established gradations. The methodical approach contains five sequential stages, such as the formation of a set of indices; determination of characteristic values of indices; normalization of indices; determination of weighting coefficients; calculation of a complex indicator. In the methodical support, the set of banking security indices has been expanded to ten and includes indices that are important from the point of view of lending to the development of the economy and the economic security of the banking sector as a type of entrepreneurship. The characteristic values of the proposed indices have been determined. The weighting coefficients of indices are set by an expert method. The normalization of the index values was carried out by the calculation method. The complex indicator value of the banking security for the analyzed period is increasing, which indicates a decrease in its level. Now the level of banking security corresponds to the dangerous gradation. The results indicate the importance of monitoring.

The monitoring algorithm based on the developed methodical support will include the following actions: collecting statistical data and calculating index values, normalizing the obtained index values, calculating a complex indicator and establishing its gradation. The results of monitoring will allow making decisions on effective tools to improve the state of banking security in the country.

\section{References}

Arnold, B., Borio, C., Ellis, L., Moshirian, F. (2012). Systemic risk, macroprudential policy frameworks, monitoring financial systems and the evolution of capital adequacy // Journal of Banking \& Finance. Vol. 36(12): 31253132. - https://doi.org/10.1016/j.jbankfin.2012.07.023.

Borio, C. (2011). Implementing the macro-prudential approach to financial regulation and supervision // The financial crisis and the regulation of finance. 101-117. -https://ideas.repec.org/h/elg/eechap/14248_7.html.

Bukhtiarova, A., Semenog, A., Razinkova, M., Nebaba, N., Haber, J.A. (2020). Assessment of financial monitoring efficiency in the banking system of Ukraine // Banks and Bank Systems. Vol. 15(1): 98-106. http://dx.doi.org/10.21511/bbs.15(1).2020.10.

Cooper, E.W. (2009). Monitoring and governance of private banks // The Quarterly Review of Economics and Finance. Vol. 49(2): 253-264. - https://doi.org/10.1016/j.qref.2008.04.002.

Danylchuk, H., Kovtun, O., Kibalnyk, L., Sysoiev, O. (2020). Monitoring and modelling of cryptocurrency trend resistance by recurrent and R/S-analysis // E3S Web of Conferences. Vol. 166: 13030. https://doi.org/10.1051/e3sconf/202016613030.

Diatlova Yu. (2018). Mechanism of sustainability regulation of the financial system and the banking sector of economy in globalization and integration conditions. In: The Economics of the XXI Century: Current State and 


\author{
Management Theory and Studies for Rural Business and Infrastructure Development \\ eISSN 2345-0355. 2021. Vol. 43. No. 2: 206 -216 \\ Article DOI: https://doi.org/10.15544/mts.2021.17
}

$\begin{array}{lcccc}\begin{array}{l}\text { Development } \\ \text { pp. }\end{array} & \text { Prospects: } & \text { monograph. } & \text { London: } & \text { Sciemcee } \\ \text { https://books.google.com.ua/books/about/The_Economics_of_the_XXI_Century. }\end{array}$

html?id=4FgIvgEACAAJ\&redir_esc=y.

Fokina-Mezentseva, K., Melnyk, T., Diatlova, V., Buhas, V., Shatska, Z. (2020). Determination of the critical risk zone for the indicator of foreign trade import coverage by the export of goods and services subject to its normal distribution // International journal of scientific \& technology research. Vol. 9, 03: 4843-4847. https://www.ijstr.org/research-paper-publishing.php?month=mar2020.

Hale, G., Lopez, J.A. (2019). Monitoring banking system connectedness with big data // Journal of Econometrics. Vol. 212(1): 203-220. - https://doi.org/10.24148/wp2018-01.

Hui, X., Zhang, A. (2020). Construction and empirical research on the dynamic provisioning model of China's banking sector under the macro-prudential framework // Sustainability (Switzerland). Vol. 12(20): 1-26. https://doi.org/10.3390/su12208527.

Kwilinski, A., Dielini, M., Mazuryk, O., Filippov, V., Kitseliuk, V. (2020). System constructs for the investment security of a country // Journal of Security and Sustainability. Vol. 10(1): 345-358. https://doi.org/10.9770/jssi.2020.10.1(25).

Leonov, S., Yarovenko, H., Boiko, A., Dotsenko, T. (2019). Prototyping of information system for monitoring banking transactions related to money laundering // SHS Web Conf. The $8^{\text {th }}$ International Conference on Monitoring, Modeling \& Management of Emergent Economy (M3E2 2019). Vol.65: $04013 . \quad-$ https://doi.org/10.1051/shsconf/20196504013.

Mardonakulovich, B.M., \& Abdurakhmanova, M.F.Q. (2020). Organization of credit obligations and monitoring of commercial banks // Academicia: An International Multidisciplinary Research Journal. Vol. 10(5): 1635-1641. https://www.ijtsrd.com/papers/ijtsrd33156.pdf.

McPhilemy, S. (2016). Integrating macro-prudential policy: central banks as the 'third force'in EU financial reform // West European Politics. Vol. 39(3): 526-544. -https://doi.org/10.1080/01402382.2016.1143243.

Methodical recommendations for calculating the level of economic security of Ukraine: Order of the Ministry of economic development and trade of Ukraine dated 29.10.2013 No 1277 . https://zakon.rada.gov.ua/rada/show/v1277731-13. Accessed 21 November 2020.

Mihus, I.P., Haman, P.I., Andriyenko, M.V., Koval, Y.S. (2019). The state of economic security of Ukrainian banking institutions and the effect of economic reforms on formation of anti-crisis measures // Financial and credit activity: problems of theory and practice. Vol. 2(29): 32-43. - https://doi.org/10.18371/fcaptp.v2i29.171997.

Onyshchuk, S.V., Onyshchuk, I.I., Petroye, O., Chernysh, R. (2020). Financial stability and its impact on national security state: Organizational and legal aspects // International Journal of Economics and Business Administration. Vol. 8(1): 353-365.

Ponomarenko, T., Prokopenko, O., Kuzmenko, H., Kaminska, T., Luchyk, M. (2018). Banking security of Ukraine: Current state and ways to improve // Banks \& bank systems. Vol. 13 (2): 77-88. http://dx.doi.org/10.21511/bbs.13(2).2018.07.

Pradhan, R.P., Arvin, M.B., Nair, M., Hall, J.H., Gupta, A. (2017). Is there a link between economic growth and insurance and banking sector activities in the G-20 countries? // Review of Financial Economics. Vol. 33: 12-28. https://doi.org/10.1016/j.rfe.2017.02.002.

Statistics. National Bank of Ukraine. - https://bank.gov.ua/ua/statistic/sector-financial/data-sector-financial\#1ms.

Zaitseva, T.V. (2020). Banking System as a Growth Pole of the Global Economy: Historical Experience and Future Perspectives // Lecture Notes in Networks and Systems. Vol. 73: 857-864. - https://doi.org/10.1007/978-3-03015160-7_86.

Zos-Kior, M., Hnatenko, I., Isai, O., Shtuler, I., Samborskyi, O., Rubezhanska, V. (2021). Management of efficiency of the energy and resource saving innovative projects at the processing enterprises // Management Theory and Studies for Rural Business and Infrastructure Development. Vol.42. No.4: 504-515. https://doi.org/10.15544/mts.2020.52

Copyright ( 2021 Author(s), published by Vytautas Magnus University. This is an open access article distributed under the terms of the Creative Commons Attribution Non-Commercial 4.0 (CC BY-NC 4.0) license, which permits unrestricted use, distribution, and reproduction in any medium provided the original author and source are credited. The material cannot be used for commercial purposes. 